\title{
Functional genomic approaches to improve crop plant heat
}

\section{stress tolerance [version 1; peer review: 2 approved, 1}

\section{approved with reservations]}

\section{Baljeet Singh (D1, Neha Salaria1, Kajal Thakur¹, Sarvjeet Kukreja², Shristy Gautam¹, Umesh Goutam (iD)}

\footnotetext{
${ }^{1}$ Molecular Biology and Genetic Engineering, Lovely Professional University, Phagwara, Punjab, 144411, India

${ }^{2}$ School of Agriculture, Lovely Professional University, Phagwara, Jalandhar, 144411, India
}

V1 First published: 04 Oct 2019, 8:1721

https://doi.org/10.12688/f1000research.19840.1

Latest published: 04 Oct 2019, 8:1721

https://doi.org/10.12688/f1000research.19840.1

\section{Abstract}

Heat stress as a yield limiting issue has become a major threat for food security as global warming progresses. Being sessile, plants cannot avoid heat stress. They respond to heat stress by activating complex molecular networks, such as signal transduction, metabolite production and expressions of heat stress-associated genes. Some plants have developed an intricate signalling network to respond and adapt it. Heat stress tolerance is a polygenic trait, which is regulated by various genes, transcriptional factors, proteins and hormones. Therefore, to improve heat stress tolerance, a sound knowledge of various mechanisms involved in the response to heat stress is required. The classical breeding methods employed to enhance heat stress tolerance has had limited success. In this era of genomics, next generation sequencing techniques, availability of genome sequences and advanced biotechnological tools open several windows of opportunities to improve heat stress tolerance in crop plants. This review discusses the potential of various functional genomic approaches, such as genome wide association studies, microarray, and suppression subtractive hybridization, in the process of discovering novel genes related to heat stress, and their functional validation using both reverse and forward genetic approaches. This review also discusses how these functionally validated genes can be used to improve heat stress tolerance through plant breeding, transgenics and genome editing approaches.

Keywords

GWAS, VIGS, T-DNA, CRISPR, Heat stress, Functional genomics

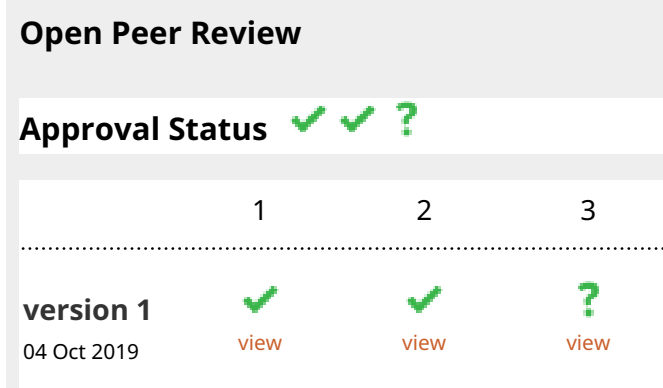

1. Himanshu Sharma, National Agri-Food Biotechnology Institute (NABI), Mohali, India

2. Neila Abdi, National Institute of Agricultural Research of Tunisia (INRAT), Tunis, Tunisia

3. Ajaya Biswal ID, University of Georgia,

Athens, USA

Any reports and responses or comments on the article can be found at the end of the article. 
Corresponding author: Umesh Goutam (umeshbiotech@gmail.com)

Author roles: Singh B: Writing - Original Draft Preparation; Salaria N: Writing - Review \& Editing; Thakur K: Writing - Review \& Editing; Kukreja S: Writing - Review \& Editing; Gautam S: Writing - Original Draft Preparation; Goutam U: Supervision, Writing - Review \& Editing

Competing interests: No competing interests were disclosed.

Grant information: The author(s) declared that no grants were involved in supporting this work.

Copyright: @ 2019 Singh B et al. This is an open access article distributed under the terms of the Creative Commons Attribution License, which permits unrestricted use, distribution, and reproduction in any medium, provided the original work is properly cited.

How to cite this article: Singh B, Salaria N, Thakur K et al. Functional genomic approaches to improve crop plant heat stress tolerance [version 1; peer review: 2 approved, 1 approved with reservations] F1000Research 2019, 8:1721

https://doi.org/10.12688/f1000research.19840.1

First published: 04 Oct 2019, 8:1721 https://doi.org/10.12688/f1000research.19840.1 


\section{Introduction}

Abiotic stresses have numerous adverse effects on crop plants, which further lead to yield and quality losses (Figure 1). To feed the whole world in the scenario of the changing climate, new and better heat tolerant varieties of various crops is needed ${ }^{1}$. The understanding of various physiological, molecular and biochemical pathways can facilitate the development of superior heat tolerant varieties ${ }^{2}$. However, previous efforts, aimed at improving plant heat stress tolerance, have had limited success $^{3,4}$ because of the poor understanding of the genetics of heat tolerance. Fortunately, nowadays reference genomes of major food crops and model plant species are available publicly, which provide a solid platform for crop improvement. Moreover, wild species and various landraces of various crops have unknown heat tolerant genes that should be identified and incorporated to high yielding modern cultivars ${ }^{5}$. The functional genomic approaches such as genome wide association studies (GWAS) and gene expression profiling using microarrays can catalyse the discovery of novel genes associated to heat stress $^{6-8}$. In addition, suppression subtractive hybridization ( $\mathrm{SSH})$ is another effective and productive technique used for the screening and cloning of the genes/ESTs that express differentially under heat stress $^{9,10}$. Reverse genetic techniques can improve the understanding of their expression patterns under heat stress. The plant breeding strategies and new biotechnological tools including genome editing techniques can use these validated genes to enhance heat stress tolerance in crop plants (Figure 2).

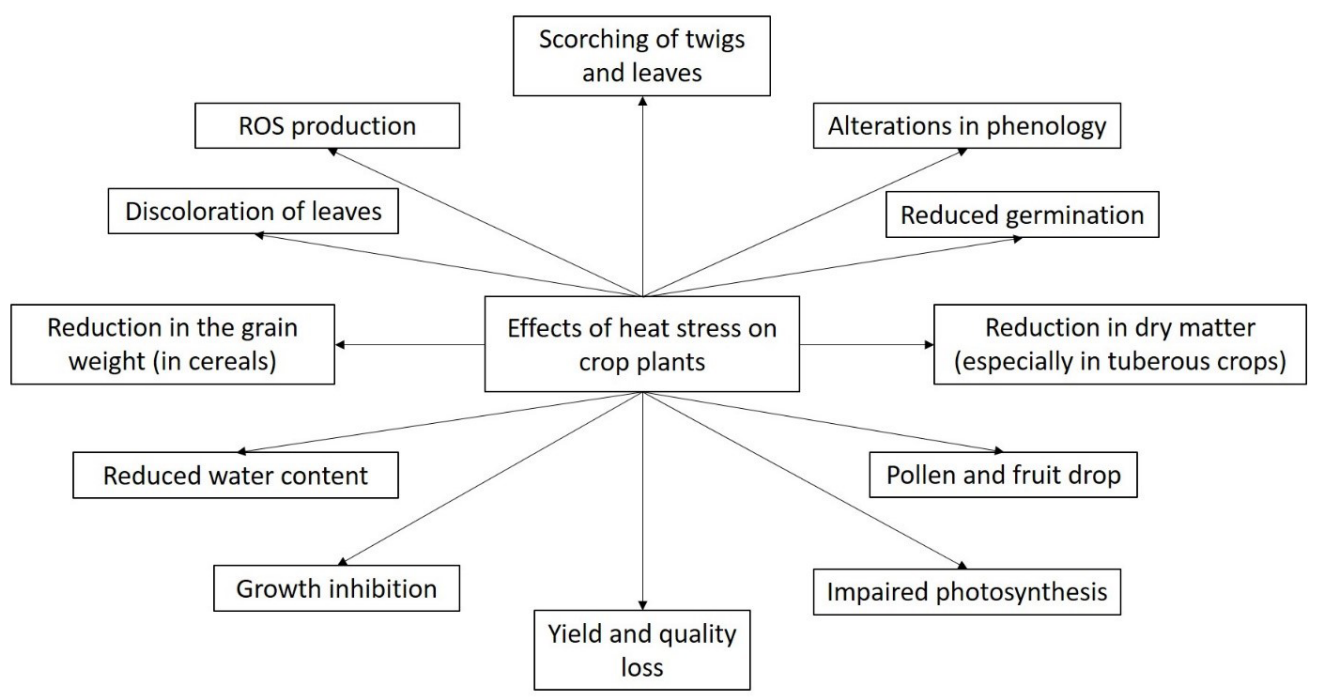

Figure 1. General effects of heat stress on crop plants.

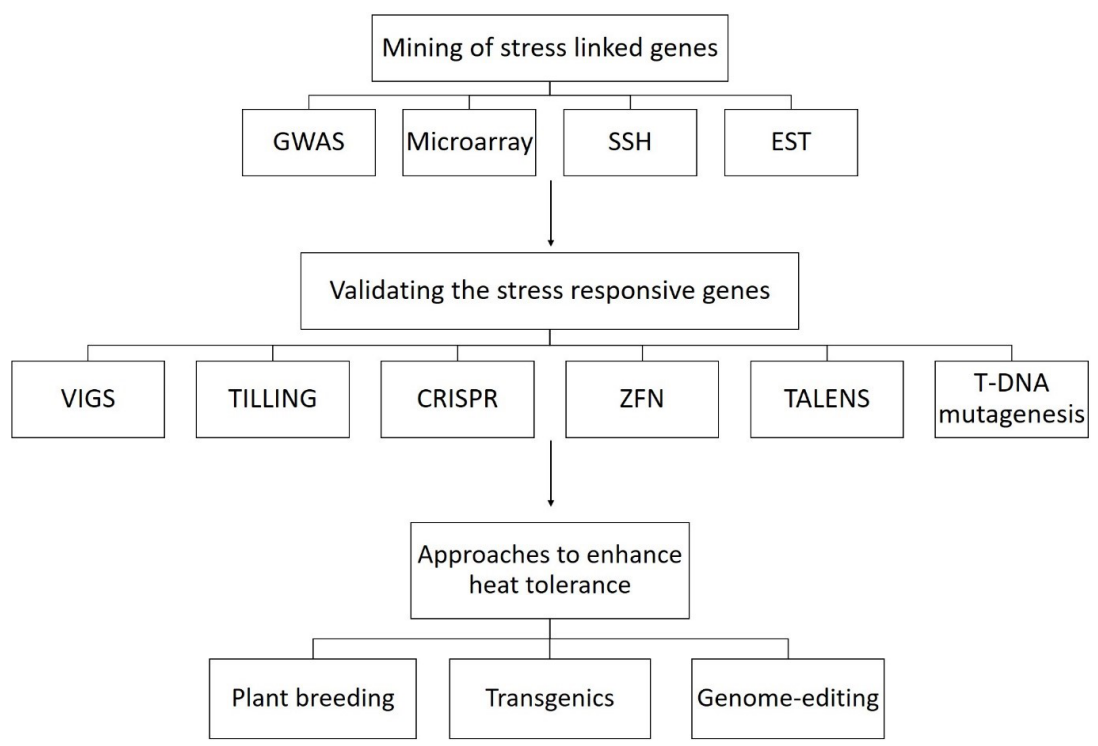

Figure 2. A systematic flow chart depicting the approaches used for the mining of genes associated with heat stress, for the functional validation of candidate genes and approaches that can take advantage of functionally validated genes to increase heat stress tolerance. 


\section{Mining of stress linked genes}

Present crop varieties have limited heat tolerance because earlier domestication, green revolution and conventional breeding were focused to increase yield and qualitative traits ${ }^{11}$. However, the knowledge of genes/markers/QTL regions associated to heat tolerance is now required to improve thermo tolerance. Previous studies suggested that vast genetic diversity still exists in the germplasms of various crops ${ }^{12-14}$. GWAS emerged as a powerful tool to identify the genetic basis behind complex phenotypic traits ${ }^{15,16}$, and it provides high mapping resolution compared with conventional genetic mapping ${ }^{17,18}$. So far this approach has been applied to major food crops, including wheat $^{7,19,20}$, rice $^{21}$, maize ${ }^{22}$, sorghum ${ }^{23}$ and Brassica napus L. ${ }^{24}$, to identify the natural variation associated with heat stress and to understand this genetic basis. Another way to identify and understand the key molecular mechanisms in response to heat stress is a transcriptomic study ${ }^{25,26}$; plants respond to heat stress by inducing various heat responsive genes, thus transcriptomic studies provide an effective screening of heat responsive candidate genes ${ }^{6}$. For example, microarray studies allow the screening of genes on the basis of their expression patterns under stressed conditions at a particular plant developmental stage $\mathrm{e}^{6,26,27}$. Singh et al. $(2015)^{6}$ investigated the heat responsive genes for potato tuberization and Ginzberg et $a l .{ }^{28}$ identified the candidate heat responsive genes for potato periderm formation using microarrays. In addition, $\mathrm{SSH}$ is an easy and efficient approach for the identification of genes/ESTs with differential expression under heat stress. This technique is preferred when the genome sequence information is not available?. It can identify the tissue specific differentially expressed transcripts. To identify heat responsive ESTs cDNA libraries can be generated from plants grown under heat stressed conditions $^{29}$. For example, SSH library of potato skin present 108 candidate genes for suberin and periderm formation ${ }^{30}$. To investigate the genes/ESTs involved in heat tolerance at the stage of grain filling in wheat, SSH library was constructed by using the leaf RNA samples from heat stressed plants ${ }^{9,29}$. The results of these studies provided many heat responsive genes/ESTs, which can be used to develop thermo tolerant wheat varieties.

\section{Validating the stress responsive genes}

The above approaches can identify potential candidate genes linked to heat stress tolerance. However, the functions of the candidate genes must be validated before incorporating them into present cultivars. Both forward and reverse genetic approaches can be employed for functional validation of genes (see examples in Table 1). Forward genetics detect variations in the nucleic acid sequence responsible for a given phenotype ${ }^{31}$, while reverse genetics detect the gene's functionality by observing the change in the phenotype due to alterations in known genetic sequence ${ }^{32}$.

Table 1. Some examples of successfully validated potential heat tolerant genes in model plants and major crops.

\begin{tabular}{|c|c|c|c|}
\hline Plant/crop & Gene & Technique used & Reference \\
\hline \multirow{6}{*}{ Arabidopsis thaliana } & HSF1 and HSF3 & $\begin{array}{l}\text { Transcription control (genetic } \\
\text { engineering using protein } \\
\text { fusion) }\end{array}$ & 33,34 \\
\hline & DREB2A CA & Microarray & 35 \\
\hline & Hsp70 & antisense gene approach & 36 \\
\hline & ATHSF1 (HSF) & Recombinant DNA technology & 33 \\
\hline & FAD7 & T-DNA & 37 \\
\hline & HSP101 & Transformation & 38 \\
\hline \multirow[t]{2}{*}{ Rice (Oryzasativa) } & spl7 & Transcription control & 39 \\
\hline & Athsp 101 & $\begin{array}{l}\text { Agrobacterium mediated } \\
\text { transformation }\end{array}$ & 40 \\
\hline \multirow[t]{2}{*}{ Wheat (Triticumaestivum) } & TamiR159 & MiR159 (miRNA) & 41 \\
\hline & TaGASR1 & $\begin{array}{l}\text { Agrobacterium mediated } \\
\text { transformation }\end{array}$ & 42 \\
\hline Carrot (Daucuscarota) & Hsp17.7 & $\begin{array}{l}\text { Hsps and molecular } \\
\text { Chaperones }\end{array}$ & 43 \\
\hline \multirow[t]{2}{*}{ Chilli pepper (Capsicum annuum) } & CabZIP63 & Virus induced gene silencing & 44 \\
\hline & CaWRKY4O & Virus induced gene silencing & 45 \\
\hline \multirow{7}{*}{ Tomato (Solanumlycopersicum) } & Hsa32 & Subtracted cDNA libraries & 46 \\
\hline & MT-sHSP & freezing transformation method & 47 \\
\hline & ATG5, ATG7, NBR1, WRKY33 & Virus induced gene silencing & 48 \\
\hline & 2-CP1, 2-CP2, 2-CP1/2, ATG5, ATG7 & Virus induced gene silencing & 49 \\
\hline & RBOH1, MPK1, MPK2 & Virus induced gene silencing & 50 \\
\hline & Hsc70.1 & Virus induced gene silencing & 51 \\
\hline & SILrgB & RNA interference & 51 \\
\hline Barley (Hordeumvulgare) & $A P X 1$ & $\begin{array}{l}\text { Agrobacterium mediated } \\
\text { transformation }\end{array}$ & 52 \\
\hline
\end{tabular}


Virus-induced gene silencing (VIGS) is a rapid, efficient and cost effective post-transcriptional gene silencing (PTGS) technique used to study target gene(s) functionality ${ }^{53}$. It can be used as both the forward and reverse genetic approach ${ }^{48,54}$. Plants can sense and then respond to heat stress by activating various transcriptional cascades ${ }^{55}$. Being a PTGS technique, VIGS can be used to knockdown the expression of target genes after transcription. VIGS takes an advantage of a plant's innate defence mechanism against virus infection. In this technique, a fragment of the target gene is first inserted into a suitable viral vector and then that vector is transformed into the plant, where the viral genome harbouring the fragment of target gene start replicating and produce dsRNA. Then an enzyme DICER cut this dsRNA into multiple siRNA of about 21 nucleotide long. Later these siRNA unwind into two single stranded RNAs, one out of which is degraded and the other one binds to RNA induced silencing complex (RISC), which later degrade the targeted endogenous gene and the effect on gene knockdown can be observed on by phenotypic analysis ${ }^{56-58}$. Many candidate genes and transcriptional factors associated with heat stress response/tolerance have been validated successfully through VIGS $^{58,59}$. For example, TRV-VIGS based silencing of CabZIP63 gene lowered the tolerance to heat stress in pepper plants, suggesting that CabZIP63 is a positive regulator for thermos tolerance ${ }^{44}$. The functionality of ATG5, ATG7,FAD7 and NtEDS1genes in response to heat stress have been successfully studied in tomato using tobacco rattle virus (TRV) based VIGS technique ${ }^{48,60}$. Recently, VIGS has also been employed to investigate the involvement of small heat shock proteins (CaHSP16.4 and CaHsp25.9) in heat stress tolerance ${ }^{61,62}$.

The role of candidate genes in heat stress tolerance can also be verified through the generation of transfer (T)-DNA mutants ${ }^{63}$. Like VIGS, insertion of T-DNA in the target gene's sequence disrupt its functionality, which results in the change of phenotype. This approach is widely accepted because of the genome wide distribution of transposable elements with superior insertions in the gene sequences, resulting in the direct gene knockout ${ }^{64}$. In addition, T-DNA can also be used as a gain of function approach to study the target gene's functionality, called as activation tagging ${ }^{65}$. For example, T-DNA having a tetramer of cauliflower mosaic virus $35 \mathrm{~S}$ promoter can cause gene activation mutations ${ }^{65}$. Since plant responses to environmental stresses are polygenic and complex traits, model plants, such as Arabidopsis, are used to first study adaptive responses ${ }^{66}$. T-DNA mutant lines of many heat tolerant ecotypes of Arabidopsis have been discovered and are available at Nottingham Arabidopsis Stock Centre (NASC) or The Arabidopsis Information Resource (TAIR).

Targeting induced local lesions in genome (TILLING) is another non-transgenic approach that allows the PCR based identification of directed mutations in the target gene sequence and the function of target gene can be analysed from the modified phenotype due to that mutation ${ }^{67,68}$. It is a fast and cost efficient technique for the screening of point mutations and for the functional validation gene of interest ${ }^{69}$. It take advantage of conventional insertional mutagenesis and availability of genomic sequences $^{70}$. These point mutations can be generated with the help of chemical mutagens such as ethyl methane sulfonate
$(E M S)^{71}$. Nowadays, the genome sequences of many crop plant species are available, which make this technique more effective. The plants under heat stress exhibit different phenotypes associated with allelic variations in their genomic sequence. The TILLING approach used to study these natural variations or SNP mutations in individuals is called as EcoTILLING. The next generation sequencing techniques allow inexpensive TILLING by sequencing method to screen SNP variations $^{72}$. Recently, the functionality of heat shock binding protein 1 (HSBP1) was examined with TILLING. The chemically induced mutations disrupted the functionality of HSBP1 partially and the mutant plants exhibited increased heat stress tolerance. These findings confirmed that HSBP1 is a negative regulator of heat stress response in tomato ${ }^{73}$.

In addition, the genome-editing techniques such as transcription activator-like effector nucleases (TALENs), zinc finger nucleases (ZFNs) and clustered regularly interspace short palindromic repeat (CRISPR) can also be used as reverse genetic approaches to study the target gene function. TALENs using sequence specific nucleases (SSNs) became a powerful genome editing technique, which can also be applied as a reverse genetic approach to understand the function of a target gene. It consists of one customizable DNA-binding domain and a nuclease, which generate double stranded DNA breaks (DSBs) at the target gene sequence ${ }^{74}$. Similar to CRISPR, these DSB are repaired either via NHEJ pathway or via homologous recombination. Both these recovery pathways allow insertion, deletion and intentional replacements in the target gene sequence. These modifications in the target gene's sequence may cause a variation in the phenotype, which suggests the function of that gene ${ }^{74,75}$. The ZFNs are the synthetic proteins having a DNA binding domain that consists two finger modules and a DNA cleaving domain. ZFNs causes DSBs in the targeted DNA sequence and facilitate site-specific mutagenesis, or base substation, which alter or may knockout the gene expression $^{76}$. The ZFNs have revealed the function of various genes in model plants as well as in crop species ${ }^{77}$.

Among all genome-editing techniques, CRISPR-Cas9 has emerged as a powerful tool for precise genome editing to study the molecular pathways linked to heat stress and to enhance thermo tolerance in crop plants ${ }^{78,79}$. It is comparatively simpler, more accurate and faster than other genome editing techniques. In brief, CRISPR involves designing of a guide RNA of $\sim 20$ nucleotides complementary to the gene of interest and a Cas9 nuclease enzyme that cut 3-4 bases next to the protospacer adjacent motif, which is later repaired either by homology directed repair pathway or via error prone non-homologous end joining ${ }^{80,81}$. Therefore, this technique can be used to generate gene knockout mutant lines to study the function of targeted gene(s). For example, annexin gene OsAnn3 knockout mutant lines developed via CRISPR-Cas9 technique revealed the role of OsAnn3 gene in cold stress tolerance in rice ${ }^{82}$.

\section{Approaches to enhance heat tolerance}

Plants have inherent mechanisms to survive under heat stressed conditions but the heat tolerance capacity of plants varies species-to-species and even within the species. If heat tolerant genes are present in sexually compatible species, then marker-assisted 
selection (MAS), new generation molecular breeding, precision breeding and genome editing techniques can be used.

Thermo tolerance is a complex multigenic trait, which is influenced by genotype $\mathrm{X}$ environment interactions ${ }^{83}$. Development of heat tolerant crop varieties through traditional breeding is very labours and time consuming. However, precision breeding with the help of MAS can accelerate the plant breeding programs with high efficiency ${ }^{84}$. SNPs and simple sequence repeats (SSR) are being used widely in plant breeding experiments aimed to enhance abiotic stress tolerance. Presently the use of SNPs become more common in plant breeding than SSR markers ${ }^{85,86}$. Garg et al..$^{87}$ found one SNP in the sequence of heat shock protein (HSP16.9) between a heat tolerant and heat susceptible wheat genotypes. This SNP contribute $29.89 \%$ phenotypic variation for grain weight per spike. Recently, many SNPs associated to heat stress tolerance have been identified in major food crops $^{7,88-90}$. However, heat stress tolerance is a polygenic trait and a single molecular marker contribute little to improve it. Therefore, it is important to incorporate several SNPs associated to various QTLs that are controlling the heat stress tolerance mechanisms ${ }^{89,91}$. However, the accessibility of genome editing techniques opened various new windows to introduce targeted editing of plant genomes to understand the molecular aspects involved in heat stress tolerance ${ }^{92,93}$. For example, ethylene response factors (ERFs) are the stress induced transcriptional factors that take part in abiotic stress tolerance. The CRISPR-Cas9 based genome editing of one such ethylene response factor from AP2/ERF superfamily enhanced abiotic stress tolerance in crop plants ${ }^{94}$.

In cases when heat tolerant genes do not exist in sexually compatible species, these methods cannot be applied. Advanced biotechnological tools can increase the limited heat stress tolerance in crop plants. The transfer of heat tolerant genes through recombinant DNA technology can generate heat tolerant transgenic lines in a short amount of time. This method also allows utilisation of potential genes from other species to enhance thermo tolerance in target crops, e.g. AmDREB2C, from Ammopiptanthus mongolicus has been used to increase heat stress tolerance in transgenic Arabidopsis plants ${ }^{95}$. In addition, many genes responsible for heat stress tolerance have been identified and validated in model plants and also in major food crops that can be introduced to heat susceptible cultivars or their expression levels can be increased by generating their stable overexpression lines. For instance, the overexpression TaPEPKR2 gene enhanced heat stress tolerance in wheat and Arabidopsis plants ${ }^{96}$.

\section{Conclusion}

Heat stress affects crop production significantly. Plants respond to heat stress by activating complex molecular networks, such as signal transduction, metabolite production and expressions of heat stress-associated genes. With the developments in plant functional genomics techniques, many novel genes related to heat stress tolerance have been identified and are being used to improve stress tolerance with the help of advanced biotechnological approaches. Next generation sequencing and genome-editing techniques will play crucial roles in crop improvement. In the near future, the scientists will have a better understanding of plant heat tolerant mechanisms and farmers will be able to grow better high yielding heat tolerant crop varieties in the fields.

\section{Data availability}

No data is associated with this article.
1. Lesk C, Rowhani P, Ramankutty N: Influence of extreme weather disasters on global crop production. Nature. 2016; 529(7584): 84-7. PubMed Abstract | Publisher Full Text

2. Fahad S, Bajwa AA, Nazir U, et al.: Crop Production under Drought and Heat Stress: Plant Responses and Management Options. Front Plant Sci. 2017; 8: 1147.

PubMed Abstract | Publisher Full Text | Free Full Text

3. Lamaoui M, Jemo M, Datla R, et al.: Heat and Drought Stresses in Crops and Approaches for Their Mitigation. Front Chem. 2018; 6: 26. PubMed Abstract | Publisher Full Text | Free Full Text

4. Grover A, Mittal D, Negi M, et al:: Generating high temperature tolerant transgenic plants: Achievements and challenges. Plant Sci. 2013; 205-206: 38-47.

PubMed Abstract | Publisher Full Text

5. Mammadov J, Buyyarapu R, Guttikonda SK, et al.: Wild Relatives of Maize, Rice, Cotton, and Soybean: Treasure Troves for Tolerance to Biotic and Abiotic Stresses. Front Plant Sci. 2018; 9: 886. PubMed Abstract | Publisher Full Text | Free Full Text

6. Singh A, Siddappa S, Bhardwaj V, et al:: Expression profiling of potato cultivars with contrasting tuberization at elevated temperature using microarray analysis. Plant Physiol Biochem. 2015; 97: 108-16. PubMed Abstract | Publisher Full Text

7. Maulana F, Ayalew H, Anderson JD, et al:: Genome-Wide Association Mapping of Seedling Heat Tolerance in Winter Wheat. Front Plant Sci. 2018; 9: 1272. PubMed Abstract | Publisher Full Text | Free Full Text

8. Duan S, Liu B, Zhang Y, et al:: Genome-wide identification and abiotic stress-responsive pattern of heat shock transcription factor family in Triticum aestivum L. BMC Genomics. 2019; 20(1): 257.

PubMed Abstract | Publisher Full Text | Free Full Text

9. Goswami S, Kumar RR, Dubey K, et al.: SSH Analysis of Endosperm Transcripts and Characterization of Heat Stress Regulated Expressed Sequence Tags in Bread Wheat. Front Plant Sci. 2016; 7: 1230.

PubMed Abstract | Publisher Full Text | Free Full Text

10. Rampuria $S$, Joshi $U$, Palit $P$, et al:: Construction and analysis of an SSH cDNA library of early heat-induced genes of Vigna aconitifolia variety RMO-40. Genome. 2012; 55(11): 783-96.

PubMed Abstract | Publisher Full Text

11. Hussain $B$ : Modernization in plant breeding approaches for improving biotic stress resistance in crop plants. Turk J Agric For. 2015; 39(4): 515-530. Publisher Full Text

12. Menguer PK, Sperotto RA, Ricachenevsky FK: A walk on the wild side: Oryza species as source for rice abiotic stress tolerance. Genet Mol Biol. 2017; 40(1 suppl 1): 238-252. PubMed Abstract | Publisher Full Text | Free Full Text

13. Lopes MS, El-Basyoni I, Baenziger PS, et al:: Exploiting genetic diversity from landraces in wheat breeding for adaptation to climate change. J Exp Bot. 2015; 66(12): 3477-86.

PubMed Abstract | Publisher Full Text

14. Machida-Hirano R: Diversity of potato genetic resources. Breed Sci. 2015; 65(1): 26-40.

PubMed Abstract | Publisher Full Text | Free Full Text

15. Visscher PM, Wray NR, Zhang Q, et al.: 10 Years of GWAS Discovery: Biology, 
Function, and Translation. Am J Hum Genet. 2017; 101(1): 5-22. PubMed Abstract | Publisher Full Text | Free Full Text

16. Challa S, Neelapu NRR: Genome-Wide Association Studies (GWAS) for Abiotic Stress Tolerance in Plants. In Biochemical, Physiological and Molecular Avenues for Combating Abiotic Stress Tolerance in Plants. 2018; 135-50. Publisher Full Text

17. Zargar SM, Raatz $\mathrm{B}$, Sonah $\mathrm{H}$, et al:: Recent advances in molecular marker techniques: Insight into QTL mapping, GWAS and genomic selection in plants. Journal of Crop Science and Biotechnology. 2015; 18(5): 293-308. Publisher Full Text

18. Lu F, Romay MC, Glaubitz JC, et al.: High-resolution genetic mapping of maize pan-genome sequence anchors. Nat Commun. 2015; 6:6914. PubMed Abstract | Publisher Full Text | Free Full Text

19. Valluru R, Reynolds MP, Davies WJ, et al.: Phenotypic and genome-wide association analysis of spike ethylene in diverse wheat genotypes under heat stress. New Phytol. 2017; 214(1): 271-283. PubMed Abstract | Publisher Full Tex

20. Li L, Mao X, Wang J, et al.: Genetic dissection of drought and heat-responsive agronomic traits in wheat. Plant Cell Environ. 2019; 42(9): 2540-2553. PubMed Abstract | Publisher Full Text

21. Patishtan J, Hartley TN, Fonseca de Carvalho R, et al.: Genome-wide association studies to identify rice salt-tolerance markers. Plant Cell Environ. 2018; 41(5) 970-982.

PubMed Abstract | Publisher Full Text

22. Gao J, Wang S, Zhou Z, et al.: Linkage mapping and GWAS reveal candidate genes conferring thermotolerance of seed-set in maize. J Exp Bot. 2019; pii: erz171.

PubMed Abstract | Publisher Full Text

23. Chen J, Chopra R, Hayes C, et al:: Genome-Wide Association Study of Developing Leaves' Heat Tolerance during Vegetative Growth Stages in a Sorghum Association Panel. Plant Genome. 2017; 10(2). PubMed Abstract | Publisher Full Text

24. Rahaman M, Mamidi S, Rahman M: Genome-wide association study of heat stress-tolerance traits in spring-type Brassica napus L. under controlled conditions. Crop J. 2018; 6(2): 115-125. Publisher Full Text

25. Zhang SS, Yang H, Ding L, et al.: Tissue-Specific Transcriptomics Reveals an Important Role of the Unfolded Protein Response in Maintaining Fertility upon Heat Stress in Arabidopsis. Plant Cell. 2017; 29(5): 1007-1023. PubMed Abstract | Publisher Full Text | Free Full Text

26. Qin $\mathrm{D}, \mathrm{Wu} \mathrm{H}$, Peng $\mathrm{H}$, et al:: Heat stress-responsive transcriptome analysis in heat susceptible and tolerant wheat (Triticum aestivum L.) by using Wheat Genome Array. BMC Genomics. 2008; 9: 432. PubMed Abstract | Publisher Full Text | Free Full Text

27. Sham A, Moustafa K, Al-Ameri S, et al.: Identification of Arabidopsis candidate genes in response to biotic and abiotic stresses using comparative microarrays. PLoS One. 2015; 10(5): e0125666. PubMed Abstract | Publisher Full Text | Free Full Text

28. Ginzberg I, Barel G, Ophir R, et al:: Transcriptomic profiling of heat-stress response in potato periderm. $J$ Exp Bot. 2009; 60(15): 4411-21. PubMed Abstract | Publisher Full Text

29. Vishwakarma $\mathrm{H}$, Junaid $\mathrm{A}$, Manjhi J, et al.: Heat stress transcripts, differential expression, and profiling of heat stress tolerant gene TaHsp90 in Indian wheat (Triticum aestivum L.) cv C306. PLoS One. 2018; 13(6): e0198293. PubMed Abstract | Publisher Full Text | Free Full Text

30. Soler M, Serra O, Fluch S, et al:: A potato skin SSH library yields new candidate genes for suberin biosynthesis and periderm formation. Planta. 2011; 233(5): 933-45.

PubMed Abstract | Publisher Full Text

31. Ji Q: Gene Identification: Forward Genetics. In: Diagnostics in Plant Breeding Dordrecht: Springer Netherlands; 2013; 41-60. Publisher Full Text

32. Bahuguna RN, Gupta P, Bagri J, et al.: Forward and reverse genetics approaches for combined stress tolerance in rice. Indian Journal of Plant Physiology. 2018; 23(4): 630-646. Publisher Full Text

33. Lee JH, Hübel A, Schöffl F: Derepression of the activity of genetically engineered heat shock factor causes constitutive synthesis of heat shock proteins and increased thermotolerance in transgenic Arabidopsis. Plant $J$. 1995; 8(4): 603-12.

PubMed Abstract | Publisher Full Text

34. Prändl R, Hinderhofer K, Eggers-Schumacher G, et al:: HSF3, a new heat shock factor from Arabidopsis thaliana, derepresses the heat shock response and confers thermotolerance when overexpressed in transgenic plants. Mol Gen Genet. 1998; 258(3): 269-78.

PubMed Abstract | Publisher Full Text

35. Sakuma $\mathrm{Y}$, Maruyama K, Qin F, et al.: Dual function of an Arabidopsis transcription factor DREB2A in water-stress-responsive and heat-stressresponsive gene expression. Proc Natl Acad Sci. 2006; 103(49): 18822-7. PubMed Abstract | Publisher Full Text | Free Full Text

36. Lee JH, Schöffl F: An Hsp70 antisense gene affects the expression of HSP70/ HSC70, the regulation of HSF, and the acquisition of thermotolerance in transgenic Arabidopsis thaliana. Mol Gen Genet. 1996; 252(1-2): 11-9. PubMed Abstract | Publisher Full Text
37. Murakami $\mathrm{Y}$, Tsuyama M, Kobayashi $\mathrm{Y}$, et al:: Trienoic fatty acids and plant tolerance of high temperature. Science. 2000; 287(5452): 476-9. PubMed Abstract | Publisher Full Text

38. Queitsch C, Hong SW, Vierling E, et al.: Heat shock protein 101 plays a crucial role in thermotolerance in Arabidopsis. Plant Cell. 2007; 12(4): 479-92. PubMed Abstract | Publisher Full Text | Free Full Text

39. Yamanouchi U, Yano M, Lin H, et al:: A rice spotted leaf gene, Spl7, encodes a heat stress transcription factor protein. Proc Natl Acad Sci. 2002; 99(11): $7530-5$.

PubMed Abstract | Publisher Full Text | Free Full Text

40. Katiyar-Agarwal S, Agarwal M, Grover A: Heat-tolerant basmati rice engineered by over-expression of $\boldsymbol{h s p 1 0 1}$. Plant Mol Biol. 2003; 51(5): 677-86. PubMed Abstract | Publisher Full Text

41. Wang $\mathrm{Y}$, Sun F, Cao H, et al:: TamiR159 directed wheat TaGAMYB cleavage and its involvement in anther development and heat response. PLoS One. 2012; 7(11): e48445

PubMed Abstract | Publisher Full Text | Free Full Text

42. Zhang $L$, Geng $X$, Zhang $H$, et al.: Isolation and characterization of heatresponsive gene TaGASR1 from wheat (Triticum aestivum L.). J Plant Biol. 2017; 60(1): 57-65.

Publisher Full Text

43. Malik MK, Slovin JP, Hwang $\mathrm{CH}$, et al:: Modified expression of a carrot small heat shock protein gene, hsp17. 7, results in increased or decreased thermotolerancedouble dagger. Plant J. 1999; 20(1): 89-99.

PubMed Abstract | Publisher Full Text

44. Shen L, Liu Z, Yang S, et al.: Pepper CabZIP63 acts as a positive regulator during Ralstonia solanacearum or high temperature-high humidity challenge in a positive feedback loop with CaWRKY40. J Exp Bot. 2016; 67(8): 2439-51. PubMed Abstract | Publisher Full Text | Free Full Text

45. Dang FF, Wang YN, Yu L, et al:: CaWRKY40, a WRKY protein of pepper, plays an important role in the regulation of tolerance to heat stress and resistance to Ralstonia solanacearum infection. Plant Cell Environ. 2013; 36(4): 757-74. PubMed Abstract | Publisher Full Text

46. Liu NY, Ko SS, Yeh KC, et al.: Isolation and characterization of tomato Hsa32 encoding a novel heat-shock protein. Plant Sci. 2006; 170(5): 976-985. Publisher Full Text

47. Sanmiya K, Suzuki K, Egawa $Y$, et al:: Mitochondrial small heat-shock protein enhances thermotolerance in tobacco plants. FEBS Lett. 2004; 557(1-3): 265-8. PubMed Abstract | Publisher Full Text

48. Zhou J, Wang J, Yu JQ, et al:: Role and regulation of autophagy in heat stress responses of tomato plants. Front Plant Sci. 2014; 5: 174. PubMed Abstract | Publisher Full Text | Free Full Text

49. Zhao J, Liu Q, Hu P, et al:: An efficient Potato virus $X$-based microRNA silencing in Nicotiana benthamiana. Sci Rep. 2016; 6(1): 20573. PubMed Abstract | Publisher Full Text | Free Full Text

50. Nie WF, Wang MM, Xia XJ, et al:: Silencing of tomato RBOH1 and MPK2 abolishes brassinosteroid-induced $\mathrm{H}_{2} \mathrm{O}_{2}$ generation and stress tolerance. Plant, Cell Environ. 2013; 36(4): 789-803. PubMed Abstract | Publisher Full Tex

51. Zhang S, Ai G, Li M, et al:: Tomato $\operatorname{LrgB}$ regulates heat tolerance and the assimilation and partitioning of carbon. Plant Sci. 2018; 274: 309-319. PubMed Abstract | Publisher Full Text

52. Shi WM, Muramoto $\mathrm{Y}$, Ueda A, et al:: Cloning of peroxisomal ascorbate peroxidase gene from barley and enhanced thermotolerance by overexpressing in Arabidopsis thaliana. Gene. 2001; 273(1): 23-7. PubMed Abstract | Publisher Full Text

53. Senthil-Kumar M, Mysore KS: New dimensions for VIGS in plant functional genomics. Trends Plant Sci. 2011; 16(12): 656-65.

PubMed Abstract | Publisher Full Text

54. Senthil-Kumar M, Lee HK, Mysore KS: VIGS-Mediated Forward Genetics Screening for Identification of Genes Involved in Nonhost Resistance. J Vis Exp. 2013; (78): e51033.

PubMed Abstract | Publisher Full Text | Free Full Text

55. Ohama N, Sato H, Shinozaki K, et al.: Transcriptional Regulatory Network of Plant Heat Stress Response. Trends Plant Sci. 2017; 22(1): 53-65. PubMed Abstract | Publisher Full Text

56. Movahedi A, Zhang J, Sun W, et al:: Plant small RNAs: definition, classification and response against stresses. Biologia (Poland). 2018; 73(3): 285-94. Publisher Full Text

57. Senthil-Kumar M, Mysore KS: Tobacco rattle virus-based virus-induced gene silencing in Nicotiana benthamiana. Nat Protoc. 2014; 9(7): 1549-62. PubMed Abstract | Publisher Full Text

58. Singh B, Kukreja S, Salaria N, et al:: VIGS: a flexible tool for the study of functional genomics of plants under abiotic stresses. J Crop Improv. 2019; $1-38$

Publisher Full Text

59. Ramegowda V, Mysore KS, Senthil-Kumar M: Virus-induced gene silencing is a versatile tool for unraveling the functional relevance of multiple abiotic-stressresponsive genes in crop plants. Front Plant Sci. 2014; 5: 323. PubMed Abstract | Publisher Full Text | Free Full Text

60. Hiremath SS, Sajeevan RS, Nataraja KN, et al:: Silencing of fatty acid desaturase (FAD7) gene enhances membrane stability and photosynthetic efficiency under heat stress in tobacco (Nicotiana benthamiana). Indian J Exp Biol. 2017; 
55(8): 532-41.

Reference Source

61. Feng $\mathrm{XH}$, Zhang $\mathrm{HX}$, Ali M, et al: A small heat shock protein CaHsp25.9 positively regulates heat, salt, and drought stress tolerance in pepper (Capsicum annuum L.). Plant Physiol Biochem. 2019; 142: 151-62. PubMed Abstract | Publisher Full Text

62. Huang LJ, Cheng GX, Khan A, et al: CaHSP16.4, a small heat shock protein gene in pepper, is involved in heat and drought tolerance. Protoplasma. 2019; 256(1): 39-51.

PubMed Abstract | Publisher Full Text

63. Radhamony RN, Prasad AM, Srinivasan R: T-DNA insertional mutagenesis in Arabidopsis: A tool for functional genomics. Electron J Biotechnol. 2005; 8(1) Reference Source

64. An G, Lee S, Kim SH, et al.: Molecular genetics using T-DNA in rice. Plant Cell Physiol. 2005; 46(1): 14-22.

PubMed Abstract | Publisher Full Text

65. Lo SF, Fan MJ, Hsing YI, et al.: Genetic resources offer efficient tools for rice functional genomics research. Plant Cell Environ. 2016; 39(5): 998-1013. PubMed Abstract | Publisher Full Text

66. Shindo C, Bernasconi G, Hardtke CS: Natural genetic variation in Arabidopsis: tools, traits and prospects for evolutionary ecology. Ann Bot. 2007; 99(6): 1043-54.

PubMed Abstract | Publisher Full Text | Free Full Text

67. Suprasanna P, Mirajkar SJ, Patade VY, et al:: 17. Induced mutagenesis for improving plant abiotic stress tolerance. In: Mutagenesis: exploring genetic diversity of crops. 2014; 345-376.

Publisher Full Text

68. Gilliham M, Able JA, Roy SJ: Translating knowledge about abiotic stress tolerance to breeding programmes. Plant J. 2017; 90(5): 898-917. PubMed Abstract | Publisher Full Text

69. Akpinar BA, Lucas SJ, Budak H: Genomics approaches for crop improvement against abiotic stress. ScientificWorld Journal. 2013; 2013: 361921. PubMed Abstract | Publisher Full Text | Free Full Text

70. Kurowska M, Daszkowska-Golec A, Gruszka D, et al:: TILLING: a shortcut in functional genomics. J Appl Genet. 2011; 52(4): 371-90. PubMed Abstract | Publisher Full Text | Free Full Text

71. Barkley NA, Wang ML: Application of TILLING and EcoTILLING as Reverse Genetic Approaches to Elucidate the Function of Genes in Plants and Animals. Curr Genomics. 2008; 9(4): 212-26. PubMed Abstract | Publisher Full Text | Free Full Text

72. Guo $Y$, Abernathy $B$, Zeng $Y$, et al:: TILLING by sequencing to identify induced mutations in stress resistance genes of peanut (Arachis hypogaea). BMC Genomics. 2015; 16: 157.

PubMed Abstract | Publisher Full Text | Free Full Text

73. Marko D, El-shershaby A, Carriero F, et al.: Identification and Characterization of a Thermotolerant TILLING Allele of Heat Shock Binding Protein 1 in Tomato. Genes (Basel). 2019; 10(7): pii: E516. PubMed Abstract | Publisher Full Text | Free Full Text

74. Sprink T, Metje J, Hartung F: Plant genome editing by novel tools: TALEN and other sequence specific nucleases. Curr Opin Biotechnol. 2015; 32: 47-53. PubMed Abstract | Publisher Full Text

75. Mahfouz MM, Piatek A, Stewart CN Jr: Genome engineering via TALENs and CRISPR/Cas9 systems: challenges and perspectives. Plant Biotechnol J. 2014; 12(8): 1006-14.

PubMed Abstract | Publisher Full Text

76. Li WT, He M, Wang J, et al:: Zinc finger protein (ZFP) in plants-A review. Plant OMICS. 2013; 6(6): 474-480. Reference Source

77. Kim S, Kim JS: Targeted genome engineering via zinc finger nucleases. Plant Biotechnol Rep. 2011; 5(1): 9-17.

PubMed Abstract | Publisher Full Text | Free Full Text

78. Biswal AK, Mangrauthia SK, Reddy MR, et al.: CRISPR mediated genome engineering to develop climate smart rice: Challenges and opportunities. Semin Cell Dev Biol. 2019; pii: S1084-9521(18)30114-9. PubMed Abstract | Publisher Full Text

79. Nguyen $\mathrm{HC}$, Lin $\mathrm{KH}, \mathrm{Ho} \mathrm{SL}$, et al.: Enhancing the abiotic stress tolerance of plants: from chemical treatment to biotechnological approaches. Physiol Plant.
2018; 164(4): 452-466.

PubMed Abstract | Publisher Full Text

80. Jaganathan D, Ramasamy K, Sellamuthu G, et al:: CRISPR for Crop Improvement: An Update Review. Front Plant Sci. 2018; 9: 985. PubMed Abstract | Publisher Full Text | Free Full Text

81. Jiang F, Doudna JA: CRISPR-Cas9 Structures and Mechanisms. Annu Rev Biophys. 2017; 46: 505-529.

PubMed Abstract | Publisher Full Text

82. Shen $C$, Que $Z, X i a ~ Y$, et al.: Knock out of the annexin gene OsAnn3 via CRISPR/Cas9-mediated genome editing decreased cold tolerance in rice. J Plant Biol. 2017; 60(6): 539-547.

Publisher Full Text

83. Tayade R, Nguyen T, Oh SA, et al.: Effective Strategies for Enhancing Tolerance to High-Temperature Stress in Rice during the Reproductive and Ripening Stages. Plant Breed Biotechnol. 2018; 6(1): 1-18. Publisher Full Text

84. Zafar SA, Hameed A, Nawaz MA, et al.: Mechanisms and molecular approaches for heat tolerance in rice (Oryza sativa L.) under climate change scenario. J Integr Agr. 2018; 17(4): 726-38. Publisher Full Text

85. Mammadov J, Aggarwal R, Buyyarapu R, et al:: SNP markers and their impact on plant breeding. In: The Role of Bioinformatics in Agriculture. 2014; 387-413. Reference Source

86. Singh N, Choudhury DR, Singh AK, et al:: Comparison of SSR and SNP markers in estimation of genetic diversity and population structure of Indian rice varieties. PLoS One. 2013; 8(12): e84136.

PubMed Abstract | Publisher Full Text | Free Full Tex

87. Garg D, Sareen S, Dalal S, et al.: Heat shock protein based snp marker for terminal heat stress in wheat (Triticum aestivum L.). Aust J Crop Sci. 2012; 6(11): 1516-1521. Reference Source

88. Ruggieri V, Calafiore R, Schettini C, et al:: Exploiting Genetic and Genomic Resources to Enhance Heat-Tolerance in Tomatoes. Agronomy. 2019; 9(1): 22. Publisher Full Text

89. Kilasi NL, Singh J, Vallejos CE, et al.: Heat Stress Tolerance in Rice (Oryza sativa L.): Identification of Quantitative Trait Loci and Candidate Genes for Seedling Growth Under Heat Stress. Front Plant Sci. 2018; 9: 1578. PubMed Abstract | Publisher Full Text | Free Full Text

90. Yuan Y, Cairns JE, Babu R, et al:: Genome-Wide Association Mapping and Genomic Prediction Analyses Reveal the Genetic Architecture of Grain Yield and Flowering Time Under Drought and Heat Stress Conditions in Maize. Front Plant Sci. 2019; 9: 1919.

PubMed Abstract | Publisher Full Text | Free Full Text

91. Paul PJ, Samineni S, Thudi M, et al:: Molecular Mapping of QTLs for Heat Tolerance in Chickpea. Int J Mol Sci. 2018; 19(8): pii: E2166. PubMed Abstract | Publisher Full Text | Free Full Text

92. Parmar N, Singh KH, Sharma D, et al.: Genetic engineering strategies for biotic and abiotic stress tolerance and quality enhancement in horticultural crops: a comprehensive review. 3 Biotech. 2017; 7(4): 239. PubMed Abstract | Publisher Full Text | Free Full Text

93. Haque E, Taniguchi H, Hassan MM, et al:: Application of CRISPR/Cas9 Genome Editing Technology for the Improvement of Crops Cultivated in Tropical Climates: Recent Progress, Prospects, and Challenges. Front Plant Sci. 2018; 9: 617. PubMed Abstract | Publisher Full Text | Free Full Text

94. Debbarma J, Sarki YN, Saikia B, et al.: Ethylene Response Factor (ERF) Family Proteins in Abiotic Stresses and CRISPR-Cas9 Genome Editing of ERFs for Multiple Abiotic Stress Tolerance in Crop Plants: A Review. Mol Biotechnol. 2019: 61(2): 153-172. PubMed Abstract | Publisher Full Text

95. Yin Y, Jiang X, Ren M, et al.: AmDREB2C, from Ammopiptanthus mongolicus, enhances abiotic stress tolerance and regulates fatty acid composition in transgenic Arabidopsis. Plant Physiol Biochem. 2018; 130: 517-528. PubMed Abstract | Publisher Full Text

96. Zang X, Geng X, He K, et al:: Overexpression of the Wheat (Triticum aestivum L.) TaPEPKR2 Gene Enhances Heat and Dehydration Tolerance in Both Wheat and Arabidopsis. Front Plant Sci. 2018; 9: 1710.

PubMed Abstract | Publisher Full Text | Free Full Text 


\title{
Open Peer Review
}

\section{Current Peer Review Status:}

\section{Version 1}

Reviewer Report 09 January 2020

https://doi.org/10.5256/f1000research.21768.r56662

(C) 2020 Biswal A. This is an open access peer review report distributed under the terms of the Creative Commons Attribution License, which permits unrestricted use, distribution, and reproduction in any medium, provided the original work is properly cited.

\author{
Ajaya Biswal \\ Department of Biochemistry and Molecular Biology, University of Georgia, Athens, GA, USA
}

Plants are constantly exposed to different abiotic stresses. They have developed a wide variety of adaptation mechanisms through molecular, physiological, and biochemical alterations to cope with different stress conditions. Heat stress is still considered as one of the major limiting factors for crop yields. Simultaneously, heat stress significantly contributes to climate change. This review well describes the wide potential of various functional genomics strategies from gene selection and identification of heat tolerance genes to genetic manipulation by genetic engineering and genome editing. However, I have a few comments that need to be addressed:

1. The authors should have discussed the functional role of heat shock protein (HSPs) and molecular chaperones under extreme temperatures. I believe a potential discussion about the possible role of HSP/chaperones towards heat stress adaptation to plants will strengthen this review.

2. I do not find a specific reason for selecting tolerant genes from a few selected crops/plants (Table I). I encourage to refer a number of heat-tolerant gene lists from other major crops.

Is the topic of the review discussed comprehensively in the context of the current literature?

Yes

Are all factual statements correct and adequately supported by citations? Yes

Is the review written in accessible language?

Yes

Are the conclusions drawn appropriate in the context of the current research literature? Yes 
Competing Interests: No competing interests were disclosed.

Reviewer Expertise: Plant Biotechnology, Genomics, Plant cell wall, Polysaccharide and Bioenergy

I confirm that I have read this submission and believe that I have an appropriate level of expertise to confirm that it is of an acceptable scientific standard, however I have significant reservations, as outlined above.

Reviewer Report 05 December 2019

https://doi.org/10.5256/f1000research.21768.r56551

(C) 2019 Abdi N. This is an open access peer review report distributed under the terms of the Creative Commons Attribution License, which permits unrestricted use, distribution, and reproduction in any medium, provided the original work is properly cited.

\section{Neila Abdi}

Field Crop Laboratory, National Institute of Agricultural Research of Tunisia (INRAT), Tunis, Tunisia

During review process, I appreciated this study. Authors discuss new approach that is well written. However, I found following points to be check for further improvement in manuscript:

Abstract: Please correct "in this area" instead of "in this era".

Introduction: Please replace "tolerant varieties" instead of "new and better heat tolerant varieties".

The conclusion need to be ameliorate because it is very brief.

The review discussed very well and comprehensively the context of current literature.

All statements are correct and author can refer to others citations to make the paper more supported.

The review is written with good English and it did not need any improvement.

Author can refer the following paper to explain more:

Zafar S.A., Zaidi S.S.A., Gaba Y., Singla-Pareek S.L., Dhankher O.P., Li X., Mansoor S., Pareek A (2019). Engineering abiotic stress tolerance via CRISPR/ Cas-mediated genome editing. Journal of Experimental Botany, doi:10.1093/jxb/erz476, pp 1-101.

- Cushman J.C., Bohnert H.J. 2000. Genomic approaches to plant stress tolerance. Genome studies and molecular genetics, 3:117-1242.

In general, this review can be accepted with minor revision.

\section{References}

1. Zafar SA, Zaidi SS, Gaba Y, Singla-Pareek SL, et al.: Engineering Abiotic Stress Tolerance via CRISPR-Cas mediated genome editing.J Exp Bot. 2019. PubMed Abstract | Publisher Full Text

2. Cushman JC, Bohnert HJ: Genomic approaches to plant stress tolerance.Curr Opin Plant Biol. 
2000; 3 (2): 117-24 PubMed Abstract | Publisher Full Text

Is the topic of the review discussed comprehensively in the context of the current literature?

Partly

Are all factual statements correct and adequately supported by citations?

Yes

Is the review written in accessible language?

Partly

Are the conclusions drawn appropriate in the context of the current research literature? Yes

Competing Interests: No competing interests were disclosed.

Reviewer Expertise: legume-rhizobia symbiosis under abiotic constraints

I confirm that I have read this submission and believe that I have an appropriate level of expertise to confirm that it is of an acceptable scientific standard.

Reviewer Report 28 October 2019

https://doi.org/10.5256/f1000research.21768.r54724

(C) 2019 Sharma H. This is an open access peer review report distributed under the terms of the Creative Commons Attribution License, which permits unrestricted use, distribution, and reproduction in any medium, provided the original work is properly cited.

\section{Himanshu Sharma}

Agri-Biotechnology Department, National Agri-Food Biotechnology Institute (NABI), Mohali, Punjab, India

The review entitled "Functional genomic approaches to improve crop plant heat stress tolerance" is relevant considering the present climate change scenario and global food security. The review highlighted the negative effects of heat stress on crop plants. Heat stress is a major yield-limiting factor in this climate change scenario. This review presents recent achievements in understanding the molecular basis of heat tolerance in crop plants. Further, it discussed the usage of appropriate approaches from the identification of heat tolerant genes to their incorporation into cultivated crop varieties. The article is written and organised nicely but still some minor improvements can be done.

\section{Specific comments}

$\underline{\text { Title }}$

The title of the article is appropriate and accurately reflect the content of the paper. 


\section{$\underline{\text { Abstract }}$}

It represent the article nicely.

\section{Introduction}

Last two lines of introduction can be improved. Authors written reverse genetic techniques can improve the understanding of their expression patterns under heat stress. I suggest that instead of

writing reverse genetic techniques they should mention the names of these techniques.

Mining of stress linked genes

Authors mentioned: Singh et al. (2015) investigated the heat responsive genes for potato tuberization and Ginzberg et al. identified the candidate heat responsive genes for potato periderm formation using microarrays.

I suggest, either write the year with Ginzberg et al. or remove year from Singh et al. (2015) to keep the same formatting.

Validating the stress responsive genes

I found this section is very interesting.

Approaches to enhance heat tolerance

Do not write the gene name; AmDREB2C in Italics as rest of the gene names in text are not written in Italics.

Conclusion

Summarized the article in a coherent way.

Overall, the article is logically structured and well-organised, and provides a useful compilation of subject matter related to addressed topic. It is an important contribution and I highly recommend it.

Is the topic of the review discussed comprehensively in the context of the current literature?

Yes

Are all factual statements correct and adequately supported by citations?

Yes

Is the review written in accessible language?

Yes

Are the conclusions drawn appropriate in the context of the current research literature? Yes

Competing Interests: No competing interests were disclosed.

Reviewer Expertise: Plant Genetics and Genomics 
I confirm that I have read this submission and believe that I have an appropriate level of expertise to confirm that it is of an acceptable scientific standard.

The benefits of publishing with F1000Research:

- Your article is published within days, with no editorial bias

- You can publish traditional articles, null/negative results, case reports, data notes and more

- The peer review process is transparent and collaborative

- Your article is indexed in PubMed after passing peer review

- Dedicated customer support at every stage

For pre-submission enquiries, contact research@f1000.com 